\title{
Biomass allocation and seasonal non-structural carbohydrate dynamics do not explain the success of tall forbs in short alpine grassland
}

\author{
Erika Hiltbrunner ${ }^{1}\left[\right.$. Jonas Arnaiz ${ }^{1} \cdot$ Christian Körner $^{1}$
}

Received: 9 September 2020 / Accepted: 15 May 2021 / Published online: 28 May 2021

(c) The Author(s) 2021

\begin{abstract}
The majority of alpine plants are of small stature. Through their small size alpine plants are decoupled from the free atmospheric circulation and accumulate solar heat. However, a few alpine species do not follow that "rule" and protrude with their aboveground structures from the microclimatic shelter of the main canopy boundary layer. We aim at explaining the phenomenon of being tall by exploring the biomass production and carbon relations of four pairs of small and tall phylogenetically related taxa in alpine grassland. We compared species and stature-specific biomass allocation, shifts in non-structural carbohydrate (NSC) concentrations in different tissues throughout the season, and we used ${ }^{13} \mathrm{C}$ labels to track carbon transfer from leaves to belowground structures. Small and tall herbs did not differ in their above- to belowground biomass allocation. The NSC composition (starch, fructan, simple sugars) and allocation did not show a stature-specific pattern, except for higher concentrations of simple sugars in tall species during their extended shoot growth. In relative terms, tall species had higher NSC pools in rhizomes, whereas small species had higher NSC pools in roots. Our findings do not place tall alpine forbs in an exceptional category in terms of biomass allocation and carbohydrate storage. The tall versus small stature of the examined herbs does not seem to be associated with specific adjustments in carbon relations. ${ }^{13} \mathrm{C}$ pulse labelling revealed early $\mathrm{C}$ autonomy in young, unfolding leaves of the tall species, which are thus independent of the carbon reserves in the massive belowground organs.
\end{abstract}

Keywords Functional growth analysis $\cdot$ High-elevation $\cdot$ Microclimate $\cdot$ Stature $\cdot{ }^{13} \mathrm{C}$ labelling

\section{Introduction}

In the temperate zone, life conditions of alpine plants are characterised by long, cold winters with a protective snow cover, and a relatively short growing season (2.5-3.5 months). The actual climate alpine plants commonly experience during the growing season is not well represented by air temperature measured at a weather station (Körner and Larcher 1988; Scherrer et al. 2011; Körner and Hiltbrunner 2018). Owing to their small stature and dense canopies, most alpine plants operate within an aerodynamic

\section{Communicated by Paul Stoy.}

Erika Hiltbrunner

erika.hiltbrunner@unibas.ch

1 Department of Environmental Sciences, Institute of Botany, University of Basel, Schönbeinstrasse 6, 4056 Basel, Switzerland boundary layer that decouples them thermally from free atmospheric circulation. Consequently, foliage temperatures in alpine plants are not much different from those in low elevation grassland during bright daylight hours, which is reflected in their photosynthetic temperature response (Körner and Diemer 1987). Across three alpine slopes and over an entire growing season, these microclimate benefits resemble a maximum downslope shift in elevation by $1900 \mathrm{~m}$ (corresponding to a $10.5 \mathrm{~K}$ difference in surface temperature; Scherrer and Körner 2011). Hence, most alpine plants are genotypically dwarfs and profit from the sundriven canopy warming. Also, flower heads of many alpine species accumulate heat (Dietrich and Körner 2014), most likely with positive effects on plant reproduction including pollination and seed ripening. Yet, a few tall taxa in all alpine ecosystems (e.g., in the genera Gentiana, Rumex, Senecio, Veratrum) appear to disregard these benefits of small stature. Are these taxa falsifying that 'rule'? What permits tall herbs to thrive outside the protective boundary 
layer? Some of these tall herbs are confined to sheltered gullies or nutrient-rich, ruderal locations (e.g., Rumex alpinus), but others are not. Here, we explore this question with a focus on growth and carbon relations.

To build such tall structures in a very short period of time might require special biomass allocation regimes and non-structural carbon pools that can rapidly be activated and invested in growth. It is well established that biomass allocation into storage organs has a strong influence on plant growth, potentially outweighing the role of per-unitleaf area $\mathrm{C}$ assimilation (functional growth analysis; Briggs et al. 1920; Körner 1991; van der Werf et al. 1993; Poorter et al. 2000).

Biomass allocation is under strong genetic control, yielding the typical species and life form specific appearance of plants (Körner 2014). For alpine and arctic herbaceous plants, such allocation patterns converge to a surprisingly similar community means but with a substantial speciesspecific variation (Körner and Renhardt 1987; Patty et al. 2010). Alpine herbaceous plants invest more in specific storage organs and roots, and less in stems, with the mean leaf mass fraction largely conserved compared to low elevation herbs. However, these surveys did not include tall herbs. They may adopt a contrasting investment strategy.

To our best knowledge, the majority of alpine tall herbs belong to the rhizomatous group of plants. Massive rhizomes may simply act as a space holder, contributing to the persistence of a species (Klimešová et al. 2018a, b). Whether rhizomes play a greater role in their carbon economy than in rhizomatous small herbs remains to be shown. Rhizomes in tall herbs may be more conspicuous simply for their size, but the biomass fraction may not differ from that in their small relatives. Although relatively large storage organs (up to $50 \%$ of total dry mass, Patty et al. 2010) are abundant in alpine herbs, some of the most extreme, high elevation habitats are inhabited by plant species that completely lack specific storage organs but store in the bulk of their fine roots, especially, when the rooting substrate is not stable as in recently released glacier forefields (e.g., species of Cerastium, Saxifraga; Körner and Renhardt 1987).

In perennial, rhizomatous species, the rhizomes increase in size every year, resulting in differently aged rhizome parts, and some species exhibit characteristic annual increments such as in Rumex alpinus (Klimeš 1992). Such special storage organs are assumed to assist in fast spring flushing through immediate remobilisation of stored carbohydrates. In addition to structural biomass allocation, the allocation and amount of non-structural carbon compounds may also contribute to tall herb success in alpine grassland. For perennial, alpine plants, storage and recycling of carbohydrates (but also other compounds such as nutrients and lipids) may be crucial to rapidly develop and survive in a short season, and high tissue concentrations of NSC have been reported, particularly for perennial tissues. It is unresolved whether these NSC deposits are simply stores of extra-photoassimilates or represent specific reserves (Chapin et al. 1990).

The most common NSC compounds are free, simple sugars of low molecular weight (glucose, fructose, sucrose), oligosaccharides, polysaccharides of variable length and degree of polymerisation and starch (Chapin et al. 1990; Hoch et al. 2003). Fructans have been shown to rise in abundance in cool environments, thus, alpine species often reveal high fructan concentrations in different tissues (Chatterton et al. 1989). Stored NSC compounds may change considerably in the different plant compartments during the growing season. In belowground organs of alpine plants, these stores may be reduced prior to, or during bud break and early-season shoot extension (Mooney and Billings 1960; Fonda and Bliss 1966; review in Körner 2021; Orthen and Wehrmeyer 2004). This early season NSC depression may become more pronounced in tall alpine herbs, and leaf autonomy may be reached later than in small herbs. Here, pulse labelling by high concentrations of enriched ${ }^{13} \mathrm{CO}_{2}$ represents a simple method for tracing the export of newly assimilated $\mathrm{CO}_{2}$ from leaves to other organs, hence, to study leaf $\mathrm{C}$ autotrophy (Studer et al. 2014).

On the other hand, the NSC concentrations in large rhizomes can be relatively stable over time, even in differently aged rhizome sections (Klimeš et al. 1999), become lower with increasing rhizome age (Shaver and Billings 1976) or vice versa (Klimešová and Klimeš 1996). NSC stores may not be diminished at peak demand for growth, and are not necessarily ever used, since high concentrations have been found in very old or dead plant fractions (Menke and Trlica 1981; Körner 2021). Old C stores of the alpine herb Oxytropis sericea commonly not used during the growing season, were remobilised when plants were experimentally shaded, indicating that these stores became 'reserves' in an emergency (Wyka 1999). Hence, it depends on life conditions or on the degree of disturbance whether stores are reserves (Chapin et al. 1990).

In the present study, we test three specific hypotheses explaining why and how tall alpine herbs are capable to thrive outside the boundary layer of the commonly small alpine vegetation.

(1) Though tall herbs reach a higher plant height and obviously produce more aboveground biomass at peak season than small herbs, they may have a preferential dry mass allocation to belowground organs (sensu functional growth analysis) due to their dependence in rhizomes.

(2) The tall stature strongly relies on high NSC provision during growth, a pronounced remobilisation from rhizomes or storage roots and transfer to the rapidly 
expanding above-ground tissues and refilling of the reserves at the end of the growing season.

(3) As leaves of tall herbs are supplied by remobilised NSC of reserves, they achieve a later seasonal foliar C autonomy.

We applied a strict comparative approach by using four small-tall pairs of taxa of the same genus or families.

\section{Materials and methods}

The study area is situated close to the Furkapass (2436 m a.s.l.) in the Swiss central Alps in the core of the alpine belt (ca. $300 \mathrm{~m}$ above the upper, climatic treeline). Annual precipitation at study site ranges between 1400 and $1700 \mathrm{~mm}$. Strong winds in winter enlarge the variability of the annual precipitation amounts through uneven snow distribution. The growing season lasts 2.5-3.5 months, depending on local snow melt date. The mean air temperature during the warmest period (mid-June till late August) is $8-9.5^{\circ} \mathrm{C}$ and the precipitation sum during the growing season (Jun-Aug) varies between 350 and $500 \mathrm{~mm}$ (weather station at the study site, www.alpfor.ch/weather.shtml). Freezing events can occur at any time during the growing season.

The alpine plant species that were studied (small versus tall herbs, Table 1) were all perennial forbs with either individual, free-standing shoots (Ligusticum mutellina, Gnaphalium norvegicum, Gnaphalium supinum, Rumex alpestris) or monospecific clusters of shoots (clones of Gentiana punctata, Peucedanum ostruthium, Rumex alpinus, named monospecific stand hereafter). All the aboveground plant organs are newly formed each season, except for Gentiana acaulis, a species that retains its leaves for several seasons. The study species grow across short distances $(<100 \mathrm{~m})$ in four types of plant communities: both Gentiana species, Ligusticum and Gnaphalium norvegicum grow in the Caricion curvulae, the dominant alpine grassland type over siliceous bedrock dominated by Carex curvula. $P$. ostruthium and $R$. alpestris belong to tall herbfields of the Adenostylion type and $R$. alpinus is confined to locations with high soil nutrient contents due to former cattle resting (Rumicion alpini;
Delarze and Gonseth 2008). Gnaphalium supinum is a typical species of late melting snow beds, but also extends into the Caricion curvulae grassland. The majority of the plant individuals were collected around the ALPFOR research station ( $46^{\circ} 34^{\prime} 36^{\prime \prime} \mathrm{N}, 8^{\circ} 25^{\prime} 17^{\prime \prime} \mathrm{E}$, at SE exposure). A small number of additional samples were collected on the W-slopes of Blauberg ( $\left.46^{\circ} 33^{\prime} 58^{\prime \prime} \mathrm{N}, 8^{\circ} 24^{\prime} 51^{\prime \prime} \mathrm{E}\right)$. All plant individuals were collected within 2410-2520 m a.s.l.

\section{Functional growth analysis}

In order to study biomass production and dry matter allocation at peak biomass, four pairs of small versus tall plant species of the same genus or family (Table 1) were collected. However, in the Rumex pair, the smaller species R. alpestris was only slightly shorter but far more slender. In the Gnaphalium pair, the tall G. norvegicum is not very tall (ca. $15-20 \mathrm{~cm}$ height) compared to the other selected tall forbs, but much taller than $G$. supinum.

Six individuals per species were completely excavated at peak biomass, i.e., when plants were flowering (July/August 2013), including all rhizomes and roots (some fine roots may have been lost), washed and then the plant samples were separated into the following four major plant compartments (according to functional criteria, see Körner 1991, 1994): (1) leaves without petioles, (2) stems with petioles and inflorescences (without ripe seeds), (3) rhizome/thick roots (diameter $>4.5 \mathrm{~mm}$ ) and (4) smaller roots (diameter: $<4.5 \mathrm{~mm}$ ). For both Rumex and G. punctata species, the smaller roots included roots of 2-4.5 mm diameter (contrasting the thick tap roots/rhizomes) but for all other species, roots mainly consisted of small roots of $<2 \mathrm{~mm}$ in diameter.

For specific leaf area at peak biomass (SLA, $\mathrm{m}^{2} \mathrm{~kg}^{-2}$ ), the total leaf area, measured by a scanner (Epson Expression 1680, Epson, GER) and the free software ImageJ 1.38x (Rasband 2014), was divided by the leaf dry weight.

In addition to the harvest of individual plants, for the tall species G. punctata, R. alpinus and P. ostruthium that form monospecific stands, two $50 \mathrm{~cm} \times 50 \mathrm{~cm}$ plots were harvested and completely excavated (biomass and allocation parameters per $\mathrm{m}^{2}$ ). The leaf, stem, rhizome, and root mass fractions were calculated as the percentage of the plant's
Table 1 Selected pairs of small versus tall plant species of the same genus or family. For $G$. punctata/G. purpurea and $L$. mutellina/L. mutellinoides a clear distinction of the species is only possible when they are flowering

\begin{tabular}{lll}
\hline Small herbs & Tall herbs & Family \\
\hline Gentiana acaulis $\mathrm{L}$. & $\begin{array}{l}\text { Gentiana punctata } \text { L. } \\
\text { Gentiana purpurea } \mathrm{L} .\end{array}$ & Gentianaceae \\
$\begin{array}{l}\text { Ligusticum mutellina } \text { (L.) Crantz } \\
\text { Ligusticum mutellinoides Vill. }\end{array}$ & $\begin{array}{l}\text { Peucedanum ostruthium (L.) W. D. J. Koch } \\
\text { Rumex alpestris Jacq. }\end{array}$ & Apiaceae \\
Gnaphalium supinum $\mathrm{L}$. & $\begin{array}{l}\text { Rumex alpinus } \text { L. } \\
\text { Gnaphalium norvegicum } \text { Gunnerus }\end{array}$ & Polygonaceae \\
\hline
\end{tabular}

For the early phenological developmental stages $1-2$, both species could have been sampled, but for the later stages it was exclusively $G$. punctata and $L$. mutellina 
total dry biomass. Leaf area ratios (LAR) were obtained by multiplying the leaf mass fraction (LMF) with the SLA. All plant samples were dried at $80{ }^{\circ} \mathrm{C}$ for $48 \mathrm{~h}$ and prior to weighing, re-dried and cooled in a vacuum desiccator.

\section{Non-structural carbohydrate (NSC) analysis}

To assess the seasonal dynamics of non-structural carbohydrate concentrations plants were collected at four defined phenological developmental stages. Each species achieved these stages at different dates throughout the growing season 2013. Stage 1 was attained when the first leaf bud or leaf appeared (sampled between June-24 and July-12). At stage 2 , the first leaf was fully expanded and/or the flower bud became visible (sampled between July-9 and July-18), at stage 3 , the plant was flowering and aboveground biomass reached its seasonal peak (harvested between July-30 and August-16) and at stage 4, seeds became ripe and denoted as end of the growing season (sampled between Sept-2 and Sept-24).

Six individuals per species and per developmental stage were carefully dugout (for the very small G. supinum several individuals were pooled to get enough plant material). For the phenological stages 1,2 and 4, only parts of belowground organs of each individual were excavated, just to have sufficient tissue amounts for the NSC analysis, but for stage 3 at peak biomass the entire plants were excavated (see functional growth analysis). Rhizomes and roots of $R$. alpinus and $G$. punctata could be visually subdivided by years, hence, the three last years of belowground organs were analysed year by year (2010, 2011 and 2012). In $P$. ostruthium thick rhizomes are commonly connected with thinner stolons, thus, the rhizome (named "first rhizome" hereafter), the interconnecting "belowground stolon" and the subsequent rhizome (named "second rhizome") were analysed separately. All plant samples were dried at $80{ }^{\circ} \mathrm{C}$ for at least $48 \mathrm{~h}$ and then ground to a fine powder in a ball mill (Mixer Mill MM 400, Retsch, GER).

A modified version of the NSC analysis described in Wong (1990) and Hoch et al. (2002) was performed. Of each plant sample, 4-5 mg of the ground material were mixed with $2 \mathrm{ml}$ hot, distilled water and extracted for $30 \mathrm{~min}$. Two aliquots of each $200 \mu \mathrm{l}$ were mixed with either $100 \mu \mathrm{l}$ invertase (breaking sucrose into glucose and fructose) or fructanase (fructanase mixture, Megazyme International Ireland, IRE; splits fructan into fructose and glucose), and further, isomerase was added to convert fructose into glucose. Glucose was then converted enzymatically into gluconate-6-phosphate (hexokinase from Sigma-Aldrich, USA) and its concentration was determined photometrically in a 96-well microplate photometer (HR 7000, Hamilton, USA). The remaining extract was mixed with $500 \mu$ dialysed clarase ( $\alpha$-amylase from Aspergillus oryzae, Enzyme Solutions
Pty Ltd., AUS) and incubated overnight at $40{ }^{\circ} \mathrm{C}$ to digest starch to glucose. Again, a $200 \mu 1$ aliquot was mixed with fructanase. Then, the concentration of the resultant total glucose (representing total NSC) was determined photometrically as described above. The subtraction of simple soluble sugars (glucose, fructose, and sucrose; named simple sugars hereafter) from the concentration of the fructanase mixture yielded the amount of fructan. Starch was calculated as total NSC (measured on the second day) minus fructan and simple sugars. Slightly negative starch values, presumably due to matrix effects were set to zero. As standards, we used starch-, inulin- and sucrose-solutions and orchard leaves (Leco, USA). All concentrations are expressed on a dry matter basis in $\mathrm{mg} \mathrm{g}^{-1}$.

\section{NSC pools}

By combining the NSC concentrations with the dry weights of the four plant compartments, the NSC pools at peak biomass (stage 3) were estimated for individuals (in mg per plant) as well as for monospecific stands (in $\mathrm{g} \mathrm{m}^{-2}$ ).

\section{Pulse labelling with enriched $\delta^{13} \mathrm{C}$}

A pulse labelling experiment with enriched ${ }^{13} \mathrm{CO}_{2}$ was carried out in the three tall species G. punctata, R. alpinus and $P$. ostruthium to explore at what phenological stage leaves become autonomous, that is, when the leaves are exporting fresh photosynthetic products to belowground organs rather than vice versa. The ${ }^{13} \mathrm{CO}_{2}$ pulse was applied on the aboveground plant biomass of three individuals per species at two different phenological stages: (1) leaf was visible but not fully unfolded, (2) one leaf was at least fully expanded (ESM Fig. 2). We released enriched ${ }^{13} \mathrm{CO}_{2}$ from ${ }^{13} \mathrm{C}$ enriched sodium bicarbonate $\left(400 \mathrm{mg} 99 \%{ }^{13} \mathrm{C}\right.$; Cambridge Isotope Lab., USA; individual-A of $R$. alpinus at stage 1 was exposed to $200 \mathrm{mg}$ only) in a transparent, cylindrical, acrylic glass chamber placed over the plant individuals (chamber volume $=31.4 \mathrm{~L}$, equipped with five mini-ventilators and an open path infrared gas analyser; CARBOCAP® Carbon Dioxide, Probe GMP343, measuring range 0-2000 ppm $\mathrm{CO}_{2}$, Vaisala, FIN) by adding $40 \mathrm{ml}$ of $1 \mathrm{~N}$ hydrochloric acid with a syringe. The reaction generated a high $\mathrm{CO}_{2}$ concentration (mixture of ${ }^{13} \mathrm{CO}_{2}$ and ${ }^{12} \mathrm{CO}_{2}$ of $838 \pm 57 \mathrm{ppm}$; mean \pm S.E.) and plants were exposed to it for c. $30 \mathrm{~min}$. The ${ }^{13} \mathrm{C}$ pulse labels were applied to the replicated individuals during morning hours (8:00-12:00) on seven consecutive days. Leaf samples were precisely taken after $0 \mathrm{~h}, 24 \mathrm{~h}, 48 \mathrm{~h}$ and $72 \mathrm{~h}$ (expressed in days in the following). After 3 days the plant individuals were completely excavated and separated into the four major plant compartments (only youngest roots were taken). Non- ${ }^{13} \mathrm{CO}_{2}$-enriched plans served as controls. 
All plant samples were dried for $48 \mathrm{~h}$ at $80{ }^{\circ} \mathrm{C}$, ground to a fine powder and analysed for $\delta^{13} \mathrm{C}$ by mass spectrometry (elemental analyzer EA-1110; Carlo Erba Thermoquest, Milan, ITA; split interface Conflo II and mass spectrometer Delta S; Thermo Finnigan Mat, Bremen, GER) at the Paul Scherrer Institute (PSI) in Villigen (Switzerland). The isotope ratio (abundance between heavy and light isotope) was expressed in the delta $(\delta)$ notation (in \%o; Carter and Barwick 2011).

\section{Statistical analysis}

The statistical analysis primarily focused on the distinction between small and tall species. The SLA, LAR, biomass and pulse labelling data were analysed with nonparametric Kruskal-Wallis/Wilcoxon rank-sum tests. NSC data were power-transformed $\left(x^{0.3}\right)$, residual distributions were visually assessed and mixed-effects models (with the R-package nlme, Ver. 3.1-117, Pinheiro et al. 2014) for the total NSC, simple sugars, fructan, and starch concentrations (as separate dependent variables) were calculated with fixed factors: plant size (nested within plant pair), plant compartment and phenological stage, and with the random factor: plant pair. To detect the NSC differences between the compartments and the different phenological stages, for each compartment and plant species, posteriori Tukey's Honest Significant Difference (HSD) tests were performed. All statistical analysis was carried out with the software R 3.1.1 (R Core Team 2014).

\section{Results}

Except for G. norvegicum, the selected tall herbs protruded the average alpine grassland canopy height by several times. Comparing the plant height between the small and tall species, the tall species were by 2.0-13.4 times taller than the small companions, with the most extreme contrast in Gnaphalium and the smallest difference in the Rumex pair (Table 2).

\section{Specific leaf area (SLA)}

The mean specific leaf area (SLA) across all eight species was $19.4 \pm 1.4 \mathrm{~m}^{2} \mathrm{~kg}^{-1}( \pm$ S.E.), values typically reported for alpine species. However, a pronounced difference in SLA between small versus tall pairs was not observed. The SLA was higher in the tall herb of the Ligusticum /Peucedanum pair $(p=0.002)$, but in the Rumex pair it was the other way round (Table 2; $p=0.002$ ). Species of Gnaphalium had similar SLA values irrespective of the stature.

\section{Biomass allocation}

For the biomass allocation, the two different harvesting methods, namely the selection of individuals versus dense monospecific stands for three of the tall species yielded very similar mass fractions. The absolute aboveground dry matter was obviously always higher in the tall species compared to the small ones (Table 3; Wilcoxon $W=86$, $p<0.001)$. A preferential allocation to aboveground parts was detected in $G$. acaulis (small herb with evergreen foliage) and both Gnaphalium species. In the five other species, the allocation to belowground biomass dominated, irrespective of the small-tall stature, thus not supporting our hypothesis 1 (Fig. 1, Table 3). Across all species, the rhizome mass fraction $(40.2 \pm 3.5 \%$; mean \pm S.E. without the dense stand harvest data) was substantially higher than the root mass fraction $(19.5 \pm 2.2 \%)$ except for both Rumex species, with equally high root and rhizome mass fractions, and for $G$. acaulis and $G$. supinum with higher root fractions. The stem mass fraction $(20.8 \pm 1.2 \%)$ was similar to that of leaves $(20.3 \pm 2.0 \%)$. The small G. acaulis with its overwintering leaves exhibited the highest

Table 2 Plant height (including flower or bud), height ratio tall to small, specific leaf area (SLA, $\mathrm{m}^{2} \mathrm{~kg}^{-1}$ ) and leaf area ratio (LAR, m $\mathrm{kg}^{-1}$, product of LMF and SLA) at peak biomass (phenological stage 3, mean \pm S.E., $n=$ number of replicates)

\begin{tabular}{|c|c|c|c|c|c|c|c|c|}
\hline \multirow{2}{*}{$\begin{array}{l}\text { Species } \\
\text { Small/tall }\end{array}$} & \multicolumn{2}{|l|}{ Height (cm) } & \multirow{2}{*}{$\begin{array}{l}\text { Height ratio } \\
\text { Tall: small }\end{array}$} & \multicolumn{2}{|c|}{$\operatorname{SLA}\left(\mathrm{m}^{2} \mathrm{~kg}^{-1}\right)$} & \multicolumn{2}{|c|}{$\operatorname{LAR}\left(\mathrm{m}^{2} \mathrm{~kg}^{-1}\right)$} & \multirow[t]{2}{*}{$n$} \\
\hline & Small & Tall & & Small & Tall & Small & Tall & \\
\hline G. acaulis/G. punctata & $7.3 \pm 0.6^{\mathrm{a}}$ & $25.2 \pm 2.6^{\mathrm{b}}$ & 3.5 & $11.1 \pm 0.4^{\mathrm{a}}$ & $18.3 \pm 5.7^{\mathrm{a}}$ & $5.3 \pm 0.3^{\mathrm{a}}$ & $2.1 \pm 0.3^{b}$ & $5-6$ \\
\hline G. punctata stand & & & & & $13.5 \pm 0.8$ & & $2.1 \pm 0.7$ & 2 \\
\hline L. mutellina/P. ostruthium & $17.6 \pm 1.8^{\mathrm{a}}$ & $57.8 \pm 3.3^{b}$ & 3.3 & $11.1 \pm 1.0^{\mathrm{a}}$ & $17.2 \pm 0.4^{\mathrm{b}}$ & $1.3 \pm 0.2^{\mathrm{a}}$ & $2.3 \pm 0.4^{b}$ & 6 \\
\hline P. ostruthium stand & & & & & $20.8 \pm 3.3$ & & $2.4 \pm 0.2$ & 2 \\
\hline R. alpestris/R. alpinus & $38.6 \pm 0.9^{\mathrm{a}}$ & $78.3 \pm 5.2^{\mathrm{b}}$ & 2.0 & $28.5 \pm 1.1^{\mathrm{a}}$ & $18.7 \pm 1.5^{\mathrm{b}}$ & $2.1 \pm 0.2^{\mathrm{a}}$ & $1.9 \pm 0.2^{\mathrm{a}}$ & 6 \\
\hline R. alpinus stand & & & & & $19.4 \pm 0.3$ & & $1.1 \pm 0.1$ & 2 \\
\hline G. supinum/G. norvegicum & $1.1 \pm 0.1^{\mathrm{a}}$ & $15.0 \pm 0.9^{\mathrm{b}}$ & 13.4 & $23.9 \pm 2.5^{\mathrm{a}}$ & $26.2 \pm 7.9^{\mathrm{a}}$ & $7.3 \pm 0.7^{\mathrm{a}}$ & $7.2 \pm 2.0^{\mathrm{a}}$ & 6 \\
\hline
\end{tabular}

Three out of four tall species form monospecific stands (additional SLA, LAR values). Different letters indicate significant differences within pairs at $p<0.05$ (Wilcoxon rank-sum test) 
Table 3 Mean $( \pm$ S.E.) dry matter $(\mathrm{g})$ and mass fractions $(\%)$ of small $v s$. tall species and monospecific stands of three tall herbs at peak biomass (stage 3)

\begin{tabular}{|c|c|c|c|c|c|c|c|c|}
\hline \multirow{2}{*}{$\frac{\text { Species }}{\text { Small/tall }}$} & \multirow[t]{2}{*}{ Compartment } & \multicolumn{2}{|c|}{ Dry matter $(\mathrm{g})$} & \multirow{2}{*}{$\frac{\text { Dry matter }\left(\mathrm{g} \mathrm{m}^{-2}\right)}{\text { Tall stand }}$} & \multicolumn{4}{|c|}{ Mass fraction (\%) } \\
\hline & & Small & Tall & & Small & Tall & Tall stand & $p$ value \\
\hline G. acaulis/ & Leaf & $0.26 \pm 0.04$ & $1.42 \pm 0.35$ & $179.9 \pm 11.5$ & $47.6 \pm 2.4^{\mathrm{a}}$ & $13.0 \pm 1.3^{\mathrm{b}}$ & $15.2 \pm 4.2^{\mathrm{b}}$ & 0.008 \\
\hline \multirow[t]{5}{*}{ G. punctata } & Stem & $0.13 \pm 0.02$ & $1.36 \pm 0.09$ & $96.0 \pm 15.2$ & $24.8 \pm 2.5^{\mathrm{a}}$ & $14.5 \pm 1.5^{\mathrm{b}}$ & $7.7 \pm 0.5^{b}$ & 0.011 \\
\hline & Rhizome & $0.06 \pm 0.01$ & $7.22 \pm 1.14$ & $964.1 \pm 260.1$ & $10.8 \pm 2.6^{\mathrm{a}}$ & $70.8 \pm 0.8^{\mathrm{b}}$ & $75.7 \pm 4.3^{\mathrm{b}}$ & 0.006 \\
\hline & Root & $0.09 \pm 0.01$ & $0.19 \pm 0.05$ & $18.7 \pm 8.0$ & $16.7 \pm 1.2^{\mathrm{a}}$ & $1.7 \pm 0.3^{\mathrm{b}}$ & $1.4 \pm 0.3^{b}$ & 0.008 \\
\hline & Aboveground & $0.39 \pm 0.05$ & $2.78 \pm 0.42$ & $276.0 \pm 3.8$ & $72.4 \pm 3.1^{\mathrm{a}}$ & $27.5 \pm 0.8^{\mathrm{b}}$ & $22.9 \pm 4.7^{\mathrm{b}}$ & 0.007 \\
\hline & Belowground & $0.15 \pm 0.02$ & $7.40 \pm 1.19$ & $982.8 \pm 268.1$ & $27.6 \pm 3.1^{\mathrm{a}}$ & $72.5 \pm 0.8^{\mathrm{b}}$ & $77.1 \pm 4.7^{\mathrm{b}}$ & 0.007 \\
\hline L. mutellinal & Leaf & $0.17 \pm 0.05$ & $3.71 \pm 1.09$ & $117.4 \pm 7.7$ & $12.2 \pm 2.2$ & $13.5 \pm 2.1$ & $11.4 \pm 0.8$ & 0.842 \\
\hline \multirow[t]{5}{*}{ P. ostruthium } & Stem & $0.18 \pm 0.02$ & $4.94 \pm 0.96$ & $173.2 \pm 33.5$ & $15.8 \pm 2.3$ & $21.5 \pm 2.6$ & $16.6 \pm 1.0$ & 0.279 \\
\hline & Rhizome & $0.97 \pm 0.22$ & $15.67 \pm 5.23$ & $715.4 \pm 94.3$ & $70.9 \pm 3.2$ & $59.2 \pm 5.6$ & $69.1 \pm 0.2$ & 0.152 \\
\hline & Root & $0.03 \pm 0.01$ & $1.60 \pm 0.65$ & $29.8 \pm 3.9$ & $1.8 \pm 0.6$ & $5.8 \pm 2.1$ & $2.9 \pm 0.0$ & 0.433 \\
\hline & Aboveground & $0.35 \pm 0.06$ & $8.65 \pm 2.00$ & $290.6 \pm 41.2$ & $28.0 \pm 3.1$ & $35.0 \pm 3.7$ & $28.0 \pm 0.2$ & 0.237 \\
\hline & Belowground & $0.99 \pm 0.22$ & $17.28 \pm 5.59$ & $745.3 \pm 98.2$ & $72.0 \pm 3.1$ & $65.0 \pm 3.7$ & $72.0 \pm 0.2$ & 0.237 \\
\hline R. alpestris/ & Leaf & $0.30 \pm 0.07$ & $8.705 \pm 1.70$ & $168.9 \pm 1.9$ & $7.4 \pm 0.7$ & $10.3 \pm 1.5$ & $5.7 \pm 0.8$ & 0.074 \\
\hline \multirow[t]{5}{*}{ R. alpinus } & Stem & $0.48 \pm 0.08$ & $13.69 \pm 1.78$ & $519.3 \pm 135.7$ & $13.3 \pm 1.1$ & $16.8 \pm 1.9$ & $16.9 \pm 1.9$ & 0.296 \\
\hline & Rhizome & $1.65 \pm 0.46$ & $28.90 \pm 7.86$ & $1220.3 \pm 181.9$ & $39.8 \pm 2.7$ & $32.6 \pm 3.6$ & $40.5 \pm 0.3$ & 0.130 \\
\hline & Root & $1.55 \pm 0.43$ & $34.39 \pm 6.67$ & $1109.6 \pm 149.5$ & $39.5 \pm 3.2$ & $40.4 \pm 2.2$ & $36.9 \pm 0.8$ & 0.416 \\
\hline & Aboveground & $0.78 \pm 0.14$ & $22.40 \pm 3.39$ & $688.2 \pm 137.6$ & $20.8 \pm 1.5$ & $27.0 \pm 3.2$ & $22.6 \pm 1.0$ & 0.344 \\
\hline & Belowground & $3.21 \pm 0.84$ & $63.29 \pm 14.12$ & $2329.9 \pm 331.4$ & $79.2 \pm 1.5$ & $73.0 \pm 3.2$ & $77.4 \pm 1.0$ & 0.344 \\
\hline G. supinum/ & Leaf & $0.04 \pm 0.01$ & $0.12 \pm 0.01$ & & $30.8 \pm 2.2$ & $28.0 \pm 1.8$ & & 0.394 \\
\hline \multirow[t]{5}{*}{ G. norvegicum } & Stem & $0.03 \pm 0.01$ & $0.16 \pm 0.02$ & & $23.0 \pm 1.5$ & $36.7 \pm 1.4$ & & 0.002 \\
\hline & Rhizome & $0.03 \pm 0.01$ & $0.05 \pm 0.01$ & & $26.9 \pm 2.4$ & $10.7 \pm 1.0$ & & 0.002 \\
\hline & Root & $0.02 \pm 0.00$ & $0.10 \pm 0.01$ & & $19.3 \pm 1.9$ & $24.6 \pm 1.3$ & & 0.065 \\
\hline & Aboveground & $0.07 \pm 0.01$ & $0.28 \pm 0.03$ & & $53.7 \pm 2.1$ & $64.7 \pm 1.2$ & & 0.004 \\
\hline & Belowground & $0.06 \pm 0.01$ & $0.15 \pm 0.01$ & & $46.3 \pm 2.1$ & $35.3 \pm 1.2$ & & 0.004 \\
\hline
\end{tabular}

Differences between mass fractions within each pair are indicated by $p$ values and different letters $(p<0.05)$

leaf mass fraction of all species (c. $48 \%$ ). Within pairs, biomass allocation differed substantially in the Gentiana and Gnaphalium pairs. The rhizome mass fraction of the tall Gentiana was over six times higher than in the small Gentiana and in the small Gnaphalium it was over twice as high as in the tall Gnaphalium. We expected a larger stem mass fraction in tall species; however, a statistically higher stem fraction was only observed in the tall Gnaphalium species (Fig. 1, Table 3).

\section{Leaf area ratio (LAR, product of LMF and SLA)}

We anticipated a lower LAR in the small herbs. Across the eight species, the LAR was $3.7 \pm 0.4 \mathrm{~m}^{2} \mathrm{~kg}^{-1}$ and did not differ between small versus tall plants (Table 2). In the two pairs with significant differences, the LAR of the small L. mutellina was lower than the LAR of tall P. ostruthium $(p=0.026)$, but in the Gentiana pair, the opposite was the case with over twice as high LAR in the small G. acaulis $(p=0.015)$, most likely because of its high LMF.

\section{Non-structural carbohydrates (NSC)}

Generally, and independently of the stature of the species, belowground organs (rhizomes and roots) showed the highest NSC concentrations, whereas NSC concentrations were typically lower in leaves and stems (Fig. 2). Across all species and all phenological stages, absolute NSC concentrations in the rhizomes amounted to $273 \pm 10 \mathrm{mg} \mathrm{g}^{-1}$ (d. m.; mean \pm S.E.), thus, dry matter consisted of $27 \%$ of NSC. The roots had a mean NSC concentration of $367 \pm 14 \mathrm{mg} \mathrm{g}^{-1}$ and leaves contained $144 \pm 6 \mathrm{mg} \mathrm{g}^{-1}$ NSC. Fructans contributed significantly to NSC, were present in all species as well as in all biomass compartments, and also contributed to the seasonal NSC dynamics. Starch concentrations were particularly high in roots and rhizomes of the Ligusticum/Peucedanum and the Rumex pair, but nearly absent in the different compartments of both, the Gentiana and Gnaphalium pairs (Fig. 2).

The mixed-effect models analysis across all four pairs and biomass compartments showed that total NSC concentrations did not differ between species of small versus tall 
Fig. 1 Comparison of mass fractions (\% of dry biomass) \pm S.E. of the four small versus tall pairs; "stand" means monospecific stands of each of the three tall species $($ mean \pm S.E., $50 \times 50 \mathrm{~cm})$

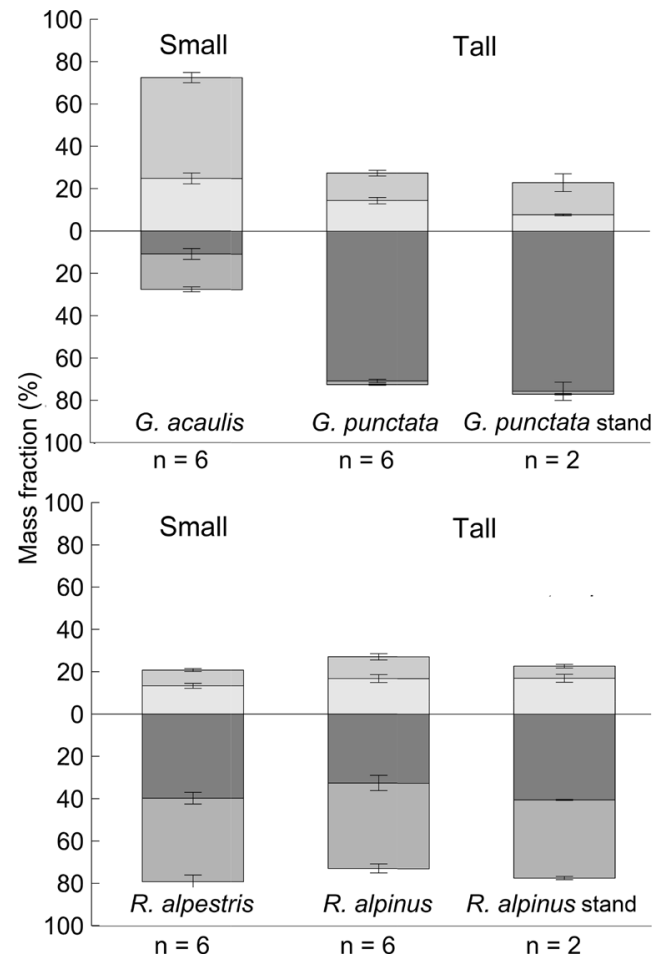

stature (Table 4), and this was also the case, when the individual NSC components were tested (Table 4). Thus, tall stature species did not differ from low stature species with respect to their NSC concentrations.

Total NSC concentrations largely differed between different compartments (highest $F$ values) and phenological stages (slightly lower $F$ values) more strongly than between species. Total NSC concentrations generally increased over the four phenological stages, but not to the same extent in the different plant compartments (see statistically significant compartment $x$ stage interaction, Table 4). For instance, the NSC concentration in rhizomes and roots slightly decreased from stage 1 to stage 2 in some of the species, which indicates a remobilisation of stored NSC for early season growth, and also the stem NSC concentration decreased from stage 3 to stage 4 (end of the season).

Simple sugar concentrations were higher in roots than rhizomes, followed by stems and leaves. Simple sugar concentrations changed with phenology and plant stature (stature x stage interaction; Table 4, Fig. 2). At stage 3 , simple sugar concentrations in stems were higher in the tall compared to the small species. Highest fructan concentrations were measured in roots followed by rhizomes. The small species had relatively higher fructan concentrations in roots and stems than the tall species (significant stature $\mathrm{x}$ compartment interaction). In those species that stored starch, concentrations were typically higher in belowground organs than in aboveground organs. Starch concentrations were lower in taller plants at stage
3 (stature $\times$ stage interaction). Because the mixed effect model across all four pairs may not mirror changes in NSC concentrations within a single plant pair, we add a few results for each pair separately.

\section{Gentiana pair}

The total NSC concentrations in the rhizomes and roots were higher in the tall species $G$. punctata than in the small G. acaulis species (Fig. 2), supporting our hypothesis 2. Interestingly, differently aged rhizome segments (2010-2012) of the tall Gentiana showed very similar seasonal variation in NSC concentrations. Thus, several yearold rhizomes still represent active storage organs in this species, also supported by the observation that rhizome segments older than five years in a 12-year-old rhizome of G. punctata stored even more NSC than younger segments due to higher concentrations of simple sugars (data not shown).

\section{Ligusticum/Peucedanum pair}

Both species showed a rather similar and steady NSC increase over the season, related to higher starch concentrations (Fig. 2). Foliar NSC concentrations were also rising over the growing season, mainly through an increase in simple sugars at stages 3 and 4 . 
Fig. 2 Non-structural carbohydrate (NSC) concentrations $($ mean \pm S.E.). NSC consisted of simple sugars, fructan and starch $\left(\mathrm{mg} \mathrm{g}^{-1} \mathrm{~d}\right.$. m.) of the four small versus tall pairs in different compartments at four phenological stages $(n=4-6)$. No stems in the Gnaphalium pair were available during the first two stages

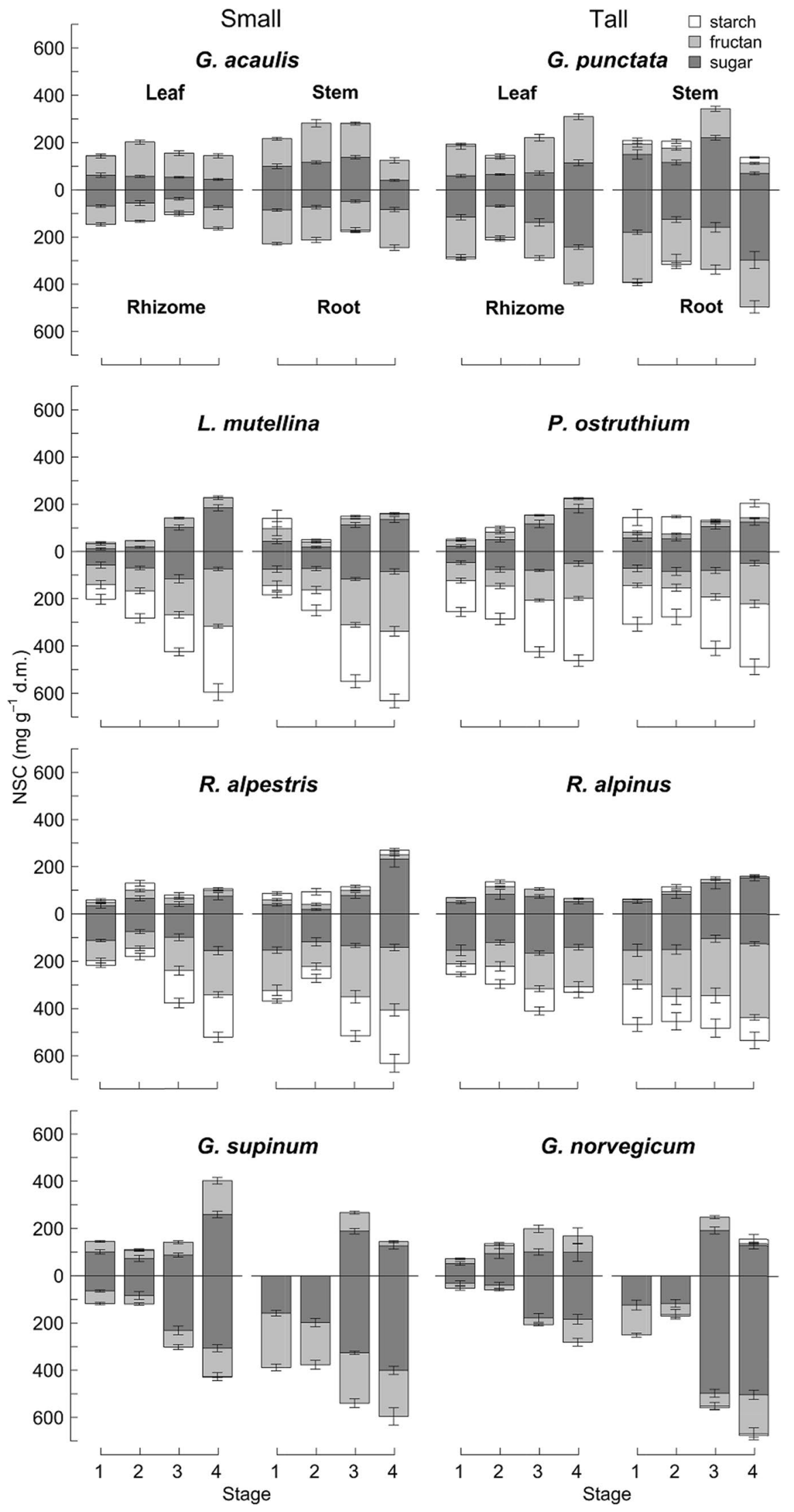


Table 4 The effect of plant stature (size), plant compartment and phenological stages on total non-structural carbohydrates (NSC), simple free sugars, fructan and starch concentrations

\begin{tabular}{|c|c|c|c|}
\hline Dependent variable & $d . f$ & $F$ & $p$ values \\
\hline \multicolumn{4}{|l|}{ Total NSC } \\
\hline (Size/pair) & 1,3 & 0.5 & 0.532 \\
\hline Compartment & 3,689 & 169.2 & $<0.001$ \\
\hline Stage & 3,689 & 69.6 & $<0.001$ \\
\hline Compartment $\mathrm{x}$ stage & 9,689 & 4.3 & $<0.001$ \\
\hline \multicolumn{4}{|l|}{ Simple sugars } \\
\hline (Size/pair) & 1,3 & 0.3 & 0.630 \\
\hline Compartment & 3,691 & 39.0 & $<0.001$ \\
\hline Stage & 3,691 & 50.0 & $<0.001$ \\
\hline Size $x$ stage & 3,691 & 2.9 & $<0.001$ \\
\hline Compartment $\mathrm{x}$ stage & 9,691 & 2.0 & $<0.001$ \\
\hline \multicolumn{4}{|l|}{ Fructan } \\
\hline (Size/pair) & 1,3 & 1.0 & 0.387 \\
\hline Compartment & 3,687 & 200.9 & $<0.001$ \\
\hline Stage & 3,687 & 16.2 & $<0.001$ \\
\hline Size $\mathrm{x}$ compartment & 3,687 & 9.8 & $<0.001$ \\
\hline Compartment $\mathrm{x}$ stage & 9,687 & 9.5 & $<0.001$ \\
\hline \multicolumn{4}{|l|}{ Starch } \\
\hline (Size/pair) & 1,3 & 0.4 & 0.558 \\
\hline Compartment & 3,683 & 65.8 & $<0.001$ \\
\hline Stage & 3,683 & 4.0 & 0.008 \\
\hline Size $x$ stage & 3,683 & 8.2 & $<0.001$ \\
\hline Compartment $\mathrm{x}$ stage & 9,683 & 5.6 & $<0.001$ \\
\hline
\end{tabular}

Small and tall species were "nested" under pair. Only compartments present in all species were included in the statistical analysis (balanced design). Models were recalculated after removing non-significant interactions terms from the models

\section{Rumex pair}

The tall Rumex species showed stable NSC concentrations in the rhizomes (analysed separately for 2010, 2011, 2012) at the beginning of the season, followed by an increase in NSC at peak biomass and a slight decrease at stage 4 . Roots emerging from a given rhizome segment had always higher NSC concentrations across the four stages than the rhizome segments. In contrast to the above-mentioned 12-year-old Gentiana punctata rhizome, a 7-year-old rhizome of a Rumex alpinus individual revealed decreasing total NSC concentrations with increasing age, and the oldest rhizome segment contained mainly simple sugars with very little fructan and starch (data not shown).

\section{Gnaphalium pair}

Both Gnaphalium species displayed a similar seasonal course in NSC, and fructan and simple free sugars were the dominating NSC compounds (Fig. 2). In the small $G$. supinum, the leaf NSC concentrations were constant from stage $1-3$, but nearly tripled towards stage 4 , exceeding leaf NSC of all other species investigated, with a mean of $403 \pm 11 \mathrm{mg} \mathrm{g}^{-1}$.

\section{NSC pools}

Irrespective of the plant stature, the belowground NSC pools were constantly larger than the aboveground NSC pools, except for the small but evergreen $G$. acaulis with a higher aboveground NSC pool (Table 5). Because of the higher overall dry matter per tall individual, NSC pools of different compartments were always larger in the tall than in the small species. However, small species always showed larger relative differences in the NSC pools between above- and belowground. For instance, in the 'small' $R$. alpestris the belowground pool was 17 times higher than the aboveground pool, whereas for the tall Rumex alpinus the belowground pool was 10 times bigger than the aboveground pool. In small species, the root NSC pool was larger than the rhizome NSC pool in three out of four small species. In the tall species $G$. punctata and $P$. ostruthium, the rhizome NSC pool surpassed root NSC pool substantially. In $R$. alpinus, with extremely high NSC pools in both root and rhizome, the root NSC pool was slightly larger than the rhizome NSC pool.

\section{Pulse labelling with enriched $\delta^{13} \mathrm{C}$}

All leaves of the plant individuals exposed to a ${ }^{13} \mathrm{CO}_{2}$ pulse had clearly higher $\delta^{13} \mathrm{C}$ values (with maximum values of $2352 \%$ ) than the control plants (foliar $\delta^{13} \mathrm{C}$ of $-25.7 \pm 0.14 \%$, mean \pm S.E.) right after pulsing (Fig. 3). Among the three tall species (Gentiana, Peucedanum and Rumex) and within each species, the $\delta^{13} \mathrm{C}$ values in leaves varied immensely, by over five-fold (ESM Table 1). However, leaf uptake was generally lower in $G$. punctata than in the other two species, despite similar $\mathrm{CO}_{2}$ concentrations (ESM Fig. 1). Leaf $\delta^{13} \mathrm{C}$ values in the three species decreased exponentially with time and after three days, leaf signals ranged between 15 and $780 \%$ (Fig. 3). In stems, the $\delta^{13} \mathrm{C}$ values were $267 \pm 70 \%$ in the early stage 1 and $294 \pm 53 \%$ in stage 2 . Even at the phenological stage 1, when leaves just emerged (ESM Fig. 2), $\delta^{13} \mathrm{C}$ values were higher in belowground organs, especially in the younger rhizomes than in controls: $2.3 \pm 13 \%$ in young rhizomes, $-16 \pm 6 \%$ in older rhizomes, and $-14 \pm 6 \%$ in roots (means \pm S.E.; $-26.8 \pm 0.2 \%$ in control rhizomes, Fig. 3 ). $G$. punctata showed very weak ${ }^{13} \mathrm{C}$ signals in the belowground organs at stage 1 , in contrast to $P$. ostruthium and $R$. alpinus with higher $\delta^{13} \mathrm{C}$ values in rhizome and roots, underpinning a very early leaf autonomy in these two species, thus falsifying our hypothesis 3 . At phenological stage 2 , a higher fraction of the applied ${ }^{13} \mathrm{C}$ pulse was translocated 
Table 5 Mean NSC pools $\left( \pm\right.$ S.E., mg plant ${ }^{-1}$ and $g$ $\mathrm{m}^{-2}$ ) in the different plant compartments of the four small $v s$. tall pairs and in monospecific stands of three tall species at peak biomass (stage 3)

\begin{tabular}{|c|c|c|c|c|c|c|c|}
\hline \multirow{2}{*}{$\begin{array}{l}\text { Species } \\
\text { Small/tall }\end{array}$} & \multirow[t]{2}{*}{ Compartment } & \multicolumn{2}{|c|}{ NSC pool (mg plant $\left.{ }^{-1}\right)$} & \multirow{2}{*}{$\begin{array}{l}\text { NSC pool }\left(\mathrm{g} \mathrm{m}^{-2}\right) \\
\text { Tall stand }\end{array}$} & \multicolumn{3}{|c|}{$\begin{array}{l}\text { Ratio below-: above- } \\
\text { ground NSC pool }\end{array}$} \\
\hline & & Small & Tall & & Small & Tall & Tall stand \\
\hline G. acaulis / & Leaf & $40 \pm 7$ & $313 \pm 83$ & $40 \pm 7$ & & & \\
\hline \multirow[t]{5}{*}{ G. punctata } & Stem & $37 \pm 5$ & $466 \pm 38$ & $33 \pm 6$ & & & \\
\hline & Rhizome & $6 \pm 1$ & $2415 \pm 426$ & $323 \pm 97$ & & & \\
\hline & Root & $16 \pm 2$ & $63 \pm 18$ & $6 \pm 3$ & & & \\
\hline & Aboveground & $77 \pm 6$ & $779 \pm 65$ & $73 \pm 9$ & & & \\
\hline & Belowground & $22 \pm 2$ & $2478 \pm 302$ & $329 \pm 97$ & 0.3 & 3.2 & 4.5 \\
\hline L. mutellinal & Leaf & $24 \pm 7$ & $572 \pm 177$ & $18 \pm 3$ & & & \\
\hline \multirow[t]{5}{*}{ P. ostruthium } & Stem & $27 \pm 3$ & $650 \pm 139$ & $23 \pm 6$ & & & \\
\hline & Rhizome & $470 \pm 111$ & $6372 \pm 2203$ & $291 \pm 60$ & & & \\
\hline & Root & $12 \pm 5$ & $635 \pm 266$ & $12 \pm 3$ & & & \\
\hline & Aboveground & $51 \pm 6$ & $1222 \pm 159$ & $41 \pm 6$ & & & \\
\hline & Belowground & $483 \pm 79$ & $7007 \pm 1569$ & $303 \pm 60$ & 9.5 & 5.7 & 7.4 \\
\hline R. alpestris / & Leaf & $26 \pm 7$ & $917 \pm 194$ & $18 \pm 2$ & & & \\
\hline \multirow[t]{5}{*}{ R. alpinus } & Stem & $56 \pm 13$ & $2003 \pm 417$ & $76 \pm 29$ & & & \\
\hline & Rhizome & $623 \pm 184$ & $12480 \pm 3490$ & $527 \pm 99$ & & & \\
\hline & Root & $802 \pm 226$ & $18848 \pm 4164$ & $608 \pm 138$ & & & \\
\hline & Aboveground & $82 \pm 11$ & $2920 \pm 325$ & $94 \pm 29$ & & & \\
\hline & Belowground & $1426 \pm 206$ & $31328 \pm 3842$ & $1135 \pm 170$ & 17.4 & 10.7 & 12.1 \\
\hline G. supinum/ & Leaf & $5 \pm 1$ & $24 \pm 4$ & & & & \\
\hline \multirow[t]{5}{*}{ G. norvegicum } & Stem & $8 \pm 1$ & $39 \pm 5$ & & & & \\
\hline & Rhizome & $10 \pm 2$ & $9 \pm 1$ & & & & \\
\hline & Root & $12 \pm 1$ & $58 \pm 3$ & & & & \\
\hline & Aboveground & $13 \pm 1$ & $63 \pm 5$ & & & & \\
\hline & Belowground & $22 \pm 2$ & $68 \pm 2$ & & 1.7 & 1.1 & \\
\hline
\end{tabular}

to rhizomes and roots, resulting in higher $\delta^{13} \mathrm{C}$ values than at stage $1(34 \pm 23 \%$ in younger and $13 \pm 20 \%$ in older rhizomes, respectively and $-11 \pm 8 \%$ in roots). Again, the ${ }^{13} \mathrm{C}$ signals in the $G$. punctata were weaker at stage 2 than in the other two species.

\section{Discussion}

The heights of the tall species examined surpassed the mean height of the surrounding typical alpine vegetation. Thus, the protruding plant parts of the tall species are assumed to be exposed to climatic conditions closer to the free atmosphere than their small stature relatives. Tall plants may experience cooler day temperatures, however, their aerodynamic coupling to the free atmosphere causes them to experience warmer night temperatures. On the other hand, aerodynamically decoupled small alpine plants heat up during bright days but may cool below air temperature in clear nights due to heat loss by outgoing thermal radiation (Körner and Hiltbrunner 2018; Monteith and Unsworth 2013). There are additional caveats of the tall- cool and small-warm 'rule'. In many tall plants, the majority of the foliage is forming a basal rosette with its own microclimate and with only the upper part of the flowering stalk and associated foliage protruding. However, this is not the case for Rumex alpinus and Peucedanum ostruthium where big leaves build a closed canopy layer with high boundary layer resistance.

Dry matter investments per foliage area (or its reverse, SLA) and the foliage produced per total plant biomass are both considered key drivers of plant growth (Poorter et al. 1990, 2015; van der Werf et al. 1998). Because LAR reflects the combination of leaf mass fraction (LMF) and SLA, and SLA was found to be the main driver of LAR (Poorter and Garnier 2007), the tall herbs with their fast growth in spring were expected to exhibit a larger SLA. However, this is not what we observed. The observed SLA across all species corresponds well with the mean SLA of $19 \mathrm{~m}^{2} \mathrm{~kg}^{-1}$ for alpine herbs at ca. $3000 \mathrm{~m}$ a.s.l. in the eastern Alps (Körner et al. 1989), and there was no small/tall distinction. The mean LAR across all species of $3.7 \pm 0.4 \mathrm{~m}^{2} \mathrm{~kg}^{-1}$ ( \pm S.E.) was slightly lower than the mean LAR of $4.5 \mathrm{~m}^{2} \mathrm{~kg}^{-1}$ across 27 small alpine herbs reported by Körner and Renhardt (1987), again without evident small/ tall differentiation. The three species with a higher LAR $\left(5-8.2 \mathrm{~m}^{2} \mathrm{~kg}^{-1}\right)$ than the overall mean: G. acaulis and both Gnaphalium species were also 
Fig. 3 Mean $\delta^{13} \mathrm{C}$ values $(\%, \pm$ S.E. $)$ of ${ }^{13} \mathrm{CO}_{2}$ pulsed three tall herbs in a leaves after $0,1,2$ and 3 days and in $\mathbf{b}$ stems, rhizomes (separated in $2012=$ rhiz -1 and $2011=$ rhiz 2) and youngest roots after 3 days at phenological stage 1 and stage 2. $Y$ axis differs in $\mathbf{a}$ and b. Gray line indicates $\delta^{13} \mathrm{C}$ value in non-enriched ${ }^{13} \mathrm{CO}_{2}$ control plants (range of -28.4 to $-24.1 \%$ o). Not all tissues were available (n. a.)
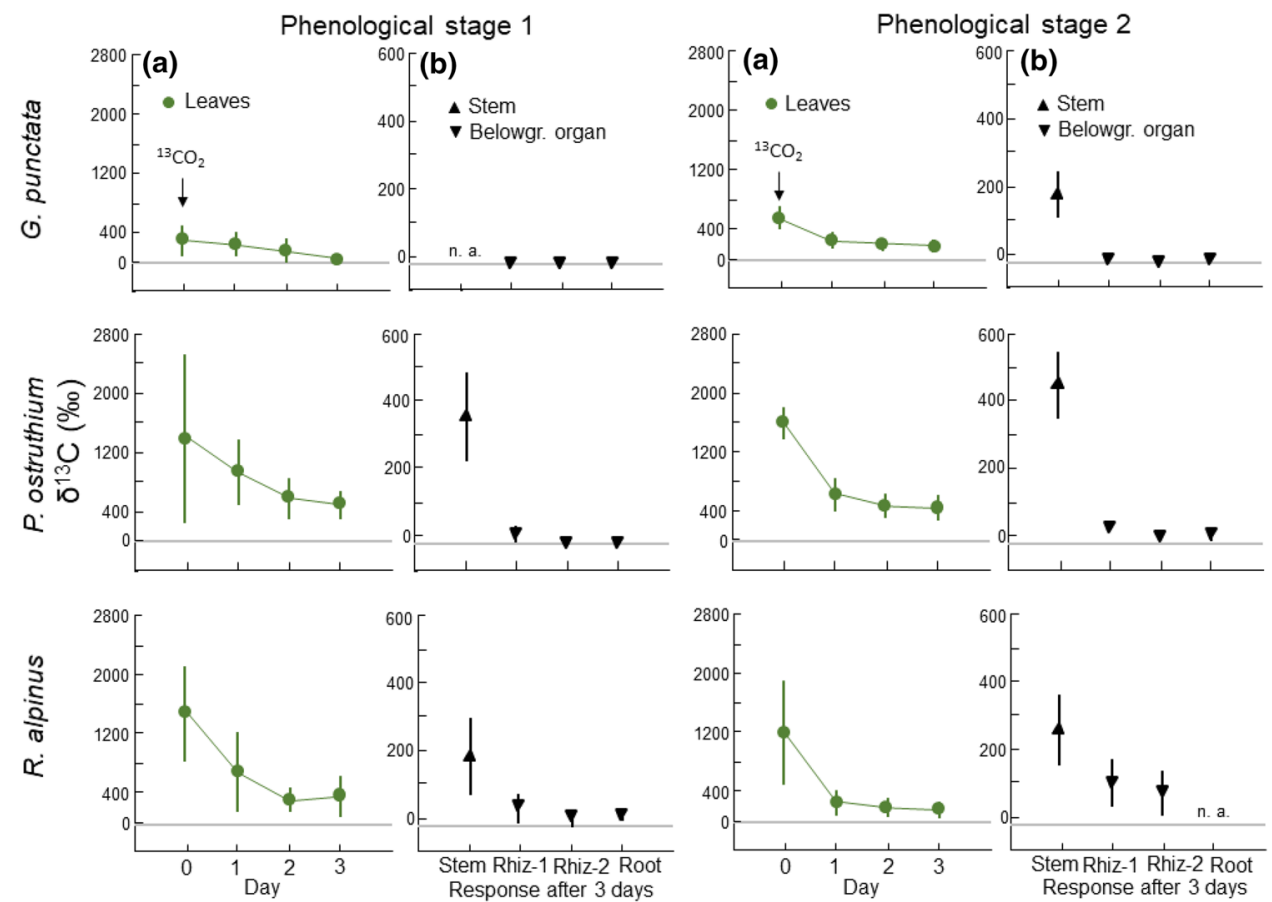

the species which preferentially allocated biomass to aboveground organs. Hence, neither SLA nor LAR permits any obvious distinction related to plant stature.

\section{Biomass allocation}

Given that biomass allocation did not differ consistently between the small versus tall species, our hypothesis 1 that tall plants need relatively bigger belowground organs to permit a rapid growth after snowmelt was not confirmed. Körner and Renhardt (1987) reported an overall lower mean rhizome fraction $(28.0 \pm 3.8 \%$ for 'storage' organs $)$, but a higher fine root fraction $(30.2 \pm 3.4 \%)$ for 27 small herbaceous alpine species than what we observed across the eight species, irrespective of their stature. Our small species had a mean leaf mass fraction of $24.5 \pm 3.5 \%$, very similar to the mean of $23.8 \pm 2.0 \%$ of other small alpine species (Körner and Renhardt 1987), while the mean LMF for the tall species was $16.2 \pm 1.7 \%$, what we attribute to the higher stem mass fraction in the tall species. Thus, in line with the LAR data, the tall herbs actually invest relatively less in leaf biomass than the small species.

\section{Non-structural carbohydrates (NSC)}

When all small versus tall plant pairs, the different biomass compartments, and the four different developmental stages were considered (in one common analysis model), the studied tall stature plants did not significantly differ from low stature species with respect to their NSC concentrations and this was also valid when simple sugar, fructan, and starch concentrations were tested separately. The higher simple sugar concentrations in stems of tall compared to small species at peak biomass may be associated with a higher phloem sap fraction, the transitory nature of stem pools (Mooney 1972).

The rise of NSC concentrations from stage 2 to 4 indicates that NSC mobilised for initial growth was rapidly restored, with foliage exporting carbon from a very early stage on (Mooney and Billings 1960; Fonda and Bliss 1966). The expected decrease in the rhizome and/ or root NSC concentrations at the beginning of the growing season (that is between stage 1 and stage 2) was only observed in rhizomes of tall G. punctata, and in roots of small $R$. alpestris and of tall G. norvegicum. The pulsing experiment with ${ }^{13} \mathrm{CO}_{2}$ revealed a "later" or commonly weaker leaf autonomy in the tall G. punctata, compared to the very early leaf autonomy in $P$. ostruthium and $R$. alpinus. And in these two species, the NSC concentrations in the belowground organs remained constant between stage 1 and stage 2 , hence, there was no obvious remobilization of NSC from these organs, thus, not supporting our hypotheses 2 and 3 .

The highest NSC concentrations across all different organs were found in the roots with up to $700 \mathrm{mg} \mathrm{g}^{-1}$ and also the highest fructan concentrations (up to $400 \mathrm{mg} \mathrm{g}^{-1}$ ) were observed in the roots. Very similar values were reported for roots of Australian alpine plant species with NSC concentrations up to $620 \mathrm{mg} \mathrm{g}^{-1}$ and fructan concentrations up to $430 \mathrm{mg} \mathrm{g}^{-1}$ (Tolsma et al. 2007). Fructans are stored in the vacuole of the plant cells and enable the plant 
to store higher NSC concentrations (Chatterton et al. 1989; Pollock and Cairns 1991). It is known that fructan synthesis is still active at low temperatures $\left(0-5{ }^{\circ} \mathrm{C}\right)$, at these temperatures plant growth is known to be more constrained than photosynthesis (Farrar 1988; Körner 2021). The high concentration of fructan across all studied species and organs calls for a routine inclusion of fructans in any NSC analysis of alpine species. Here, in our small-tall comparison, small species had higher fructan concentrations in their roots than the tall species (with a lower root mass fraction).

The data on NSC seasonal dynamics may contribute to the debate about plant priorities for either storage or growth. Chapin et al. (1990) distinguished between reserve formation (competing with growth) and accumulation of storage substances. In the Ligusticum / Peucedanum pair, the NSC concentrations in rhizomes started to increase already from stage 1 on, meaning that even when the demand for NSC in aboveground organs was substantial, storage of NSC occurred (in addition of the early leaf autonomy in $\mathrm{Peu}$ cedanum). Nevertheless, the analysis of NSC concentrations within a specific organ does not allow differentiating between existing and newly formed carbohydrates, thus, organs with high NSC concentrations may still have high turnover rates. On the other hand, NSC concentrations in the tall R. alpinus and G. punctata individuals in which we studied rhizome age effects, indicate high NSC "deposits" in old, belowground parts that do not seem to contribute to seasonal turnover. High NSC concentrations in old(er) rhizome segments may insure plants against losses of a substantial parts of their biomass (e.g., resilience under strong herbivore pressure).

In previous experiments with removal of aboveground parts, simulating damage or mowing, hence, a minor tissue loss only, the NSC concentrations in roots or rhizomes were either not affected (Latzel et al. 2013), increased (Janeček and Klimešová 2014) or slightly decreased, though not affecting the overall survival of the plant (Kleijn et al. 2005). In a pot experiment with four meadow plants, the removal of either aboveground tissues or roots caused a decrease in NSC concentrations and NSC pools in both rhizome and roots (Janeček and Klimešová 2014). Yet, in most studies with shoot removal, belowground NSC concentrations remained stable or even increased, but so far, too few studies have been carried out on damages of belowground organs and their effects. Marmots and small rodents are known to largely feed on roots and rhizomes; thus, it is rather surprising that these relationships between rhizome damages, NSC concentrations, and plant resilience have not been studied in detail. Aryal et al. (2015) reported a positive correlation between the sum of dry matter protein, carbohydrate, and fat concentrations in plants and the consumption by the Himalayan marmot, indicating selective feeding of this herbivore.
Our seasonal harvests under common alpine life conditions revealed little influence of aboveground growth -irrespective of the plant stature- on NSC concentrations in the belowground organs, so, NSC storage has an overwhelming priority for these alpine plants. Moreover, $\mathrm{CO}_{2}$ enrichment and shading experiments in situ revealed that carbon is not a limiting resource for alpine plants (Körner et al. 1997; Inauen et al. 2012; Möhl et al. 2020) and tall alpine forbs are no exception in this respect.

NSC pools size (estimated at peak biomass only) scaled symmetrically with biomass. It seems, however, that the rhizome NSC pools played a greater role in the tall stature species, whereas in the small species, roots represent the bigger NSC pool. Tall species also had a higher aboveground NSC pool than the small species because of the bigger stems. The relative pool sizes between above- versus belowground compartments displayed lower relative NSC differences in tall compared to small species. It is hard to attribute a functional significance to these relative differences. It may well be that the tall herbs simply need a strong mechanical (rhizomatous) basis for their tall shoots. In case of heavy damage, sprouts can rise directly from rhizomes, so, a network of rhizomes also contributes to resilience (Klimeš 1992; Klimešová et al. 2018a, b). The high NSC concentrations in rhizomes of tall species may contribute to tissue renewal during the remaining, short growing season. Thus, it depends on the degree and timing of disturbances whether stores become reserves in tall forbs.

Tracking ${ }^{13} \mathrm{C}$ pulse labelling signals from leaves to belowground organs helped identifying the direction and rate of $\mathrm{C}$ transfer during early growth. It is well established that leaves gain $\mathrm{C}$ autonomy, and thus, become net $\mathrm{C}$ exporters very early during their expansion. For the majority of dicotyledonous plants, the transition between cessation of import and start of export of NSC seems to occur when leaves are 30-60\% fully expanded. Import of NSC has been found to continue for a certain period, even when the export of NSC has already started (Turgeon 1989). Referring to the tall species, we expected a pronounced reserve mobilisation from the rhizomes and therefore a late achievement of $\mathrm{C}$ autonomy of the leaves. We found only in G. punctata an early seasonal decrease in the NSC concentrations of belowground organs and a later $\mathrm{C}$ autonomy in leaves.

\section{Conclusions}

The study of biomass allocation at peak biomass and NSC storage over a growing season in congeneric or closely related pairs of typically small versus exceptionally tall alpine herbs revealed that tall species are simply bigger and are not characterised by special biomass investments. 
Surprisingly, there was also no overwhelming difference in the production and use of NSC over the growing season between the tall and the small species, except for higher simple sugar concentrations in stems of tall species at biomass peak, and an overall preferential allocation of NSC to belowground organs was observed. The ${ }^{13} \mathrm{C}$ pulse labelling in tall species showed that the allocation of newly assimilated $\mathrm{C}$ to belowground organs has a high priority already from early developmental stages on, and independently of the already massive NSC stores.

Conclusively, our findings do not place tall alpine herbs in a special category in terms of biomass investment and carbohydrate storage. Growing tall is not simply related to greater belowground NSC stores. Tall species even revealed lower belowground/ aboveground ratios of their NSC pools. Thus, the means by which these tall herbs 'break the rule' seem to partly rely on the mechanical strength of these massive rhizomes. Without severe disturbances, rhizome parts may reach substantial age ( $>10$ years), fully packed with carbohydrates and contributing to the persistence of these plant species. We do not see a consistent association of tall taxa with nutrient-rich locations as was suggested by Steffen et al. (2016). While some of the studied tall herbs are clearly associated with fertile microhabitats (e.g., Rumex alpinus), others (e.g., Gentiana punctata) are clearly not. Tall alpine herbs are not facing any obvious disadvantage in their carbon relations compared to their smaller stature relatives. We infer that NSC stores are not a limiting factor for growth in the tall alpine species.

Supplementary Information The online version contains supplementary material available at https://doi.org/10.1007/s00442-021-04950-7.

Acknowledgements We would like to thank Lukas Eggimann Müller, Juliana Neumann and Sebastian Nagelmüller for the help in the field. We further thank Elena Puri for the great help with the NSC analysis and Matthias Saurer and Rolf Siegwolf for carbon isotope analysis. Infrastructure was provided by the Alpine Research and Education Station Furka ALPFOR (www.alpfor.ch) and the expenses for the NSC analysis were covered by the University of Basel (Institute of Botany). The study did not receive any further funding. We thank Katherine L. Gross and two anonymous reviewers for their detailed comments on an earlier version of this manuscript. This manuscript is to be published as part of a Special Issue honoring Russ Monson. We appreciate particularly Russ' contributions to alpine plant and ecosystem ecology, including the first evidence of non-mycorrhizal uptake of amino acids by alpine sedges and the importance of soil microbes. Russ Monson is a champion of all leagues in physiological plant ecology by covering plant carbon, nutrient and water relations from hot deserts to the high alpine and has a strong sense for scale-in space and time.

Author contribution statement $\mathrm{EH}$ and $\mathrm{CK}$ envisaged and designed the study. JA performed the study. JA and EH analysed the data. EH, $\mathrm{CK}$, and JA wrote the manuscript.

Funding Open Access funding provided by Universität Basel (Universitätsbibliothek Basel).

\section{Declarations}

Conflict of interest The authors declare that they have no conflict of interest.

Open Access This article is licensed under a Creative Commons Attribution 4.0 International License, which permits use, sharing, adaptation, distribution and reproduction in any medium or format, as long as you give appropriate credit to the original author(s) and the source, provide a link to the Creative Commons licence, and indicate if changes were made. The images or other third party material in this article are included in the article's Creative Commons licence, unless indicated otherwise in a credit line to the material. If material is not included in the article's Creative Commons licence and your intended use is not permitted by statutory regulation or exceeds the permitted use, you will need to obtain permission directly from the copyright holder. To view a copy of this licence, visit http://creativecommons.org/licenses/by/4.0/.

\section{References}

Aryal A, Brunton D, Ji W, Rothman J, Coogan SCP, Adhikari B, Su J, Raubenheimer D (2015) Habitat, diet, macronutrient, and fiber balance of Himalayan marmot (Marmota himalayana) in the Central Himalaya. Nepal J Mammal 96:308-316. https://doi.org/10. 1093/jmammal/gyv032

Briggs GE, Kidd F, West C (1920) A quantitative analysis of plant growth: part II. Ann App Biol 7:202-223. https://doi.org/10. 1111/j.1744-7348.1920.tb05308.x

Carter J, Barwick V (2011) Good practice guide for isotope ratio mass spectrometry. FIRMS.

Chapin FS, Schulze E, Mooney HA (1990) The ecology and economics of storage in plants. Ann Rev Ecol Syst 21:423-447. https://doi. org/10.1146/annurev.es.21.110190.002231

Chatterton NJ, Harrison PA, Bennett JH, Asay KH (1989) Carbohydrate partitioning in 185 accessions of Gramineae grown under warm and cool temperatures. J Plant Phys 134:169-179. https:// doi.org/10.1016/S0176-1617(89)80051-3

Delarze R, Gonseth Y (2008) Lebensräume Der Schweiz-Ökologie, Gefährdung, Kennarten, 2nd ed. hep verlag, Bern

Dietrich L, Körner C (2014) Thermal imaging reveals massive heat accumulation in flowers across a broad spectrum of alpine taxa. Alp Bot 124:27-35. https://doi.org/10.1007/s00035-014-0123-1

Farrar JF (1988) Temperature and the partitioning and translocation of carbon. In: Long SF, Woodward FI (eds) Plants and temperature. Symp Soc Exp Biol 42:203-235. The Company of Biol Ltd, Cambridge

Fonda RW, Bliss LC (1966) Annual carbohydrate cycle of alpine plants on Mt. Washington, New Hampshire. Bull Torrey Bot Club 93:268-277. https://doi.org/10.2307/2483955

Hoch G, Popp M, Körner C (2002) Altitudinal increase of mobile carbon pools in Pinus cembra suggests sink limitation of growth at the Swiss treeline. Oikos 98:361-374. https://doi.org/10.1034/j. 1600-0706.2002.980301.x

Hoch G, Richter A, Körner C (2003) Non-structural carbon compounds in temperate forest trees. Plant Cell Environ 26:1067-1081. https://doi.org/10.1046/j.0016-8025.2003.01032.x

Inauen N, Körner C, Hiltbrunner E (2012) No growth stimulation by $\mathrm{CO}_{2}$ enrichment in alpine glacier forefield plants. Glob Change Biol 18:985-999. https://doi.org/10.1111/j.1365-2486.2011. 02584.x

Janeček Š, Klimešová J (2014) Carbohydrate storage in meadow plants and its depletion after disturbance: do roots and stem-derived 
organs differ in their roles? Oecologia 175:51-61. https://doi.org/ 10.1007/s00442-014-2900-3

Kleijn D, Treier U, Müller-Schärer H (2005) The importance of nitrogen and carbohydrate storage for plant growth of the alpine herb Veratrum album. New Phytol 166:565-575. https://doi.org/10. 1111/j.1469-8137.2005.01321.x

Klimeš L (1992) The clone architecture of Rumex alpinus (Polygonaceae). Oikos 63:402. https://doi.org/10.2307/3544966

Klimeš L, Klimešová J, Čížková H (1999) Carbohydrate storage in rhizomes of Phragmites australis: The effects of altitude and rhizome age. Aquatic Bot 64:105-110

Klimešová J, Klimeš L (1996) Effects of rhizome age and nutrient availability on carbohydrate reserves in Rumex alpinus rhizomes. Biologia 51:457-461

Klimešová J, Martínková J, Tomáš Herben T (2018a) Horizontal growth: an overlooked dimension in plant trait space. Perspect Plant Ecol Evol Syst 32:18-21. https://doi.org/10.1016/j.ppees. 2018.02.002

Klimešová J, Martínková J, Ottaviani G (2018b) Belowground plant functional ecology: towards an integrated perspective. Funct Ecol 32:2115-2126. https://doi.org/10.1111/1365-2435.13145

Körner C (1991) Some often overlooked plant characteristics as determinants of plant growth: a reconsideration. Funct Ecol 5:162. https://doi.org/10.2307/2389254

Körner C (1994) Biomass fractionation in plants: a reconsideration of definitions based on plant functions. A whole plant perspective on carbon-nitrogen interactions, 173-185 pp. SPB. Academic Publishing, Hague, the Netherlands

Körner C (2014) Pflanzen im Lebensraum "Strasburger" Lehrbuch der Pflanzenwissenschaften. In: Kadereit JW, Körner C, Kost B, Sonnewald U (eds) pp. 759-810. 37th ed, Springer, Berlin, Heidelberg

Körner C (2021) Alpine plant life-functional plant ecology of high mountain ecosystems. 3rd ed. Springer, Heidelberg. https://doi. org/10.1007/978-3-030-59538-8

Körner C, Diemer M (1987) In situ photosynthetic responses to light, temperature and carbon dioxide in herbaceous plants from low and high altitude. Funct Ecol 1:179-194. https://doi.org/10.2307/ 2389420

Körner C, Hiltbrunner E (2018) The 90 ways to describe plant temperature. Perspect Plant Ecol Evol Syst 30:16-21. https://doi.org/ 10.1016/j.ppees.2017.04.004

Körner C, Larcher W (1988) Plant life in cold climates. In: Long SF, Woodward FI (eds) Plants and Temperature, Symp Soc Exp Biol 42:25-57. The Company of Biol Ltd, Cambridge

Körner C, Renhardt U (1987) Dry matter partitioning and root length/ leaf area ratios in herbaceous perennial plants with diverse altitudinal distribution. Oecologia 74:411-418. https://doi.org/10. 1007/BF00378938

Körner C, Neumayer M, Menendez-Riedl SP, Smeets-Scheel A (1989) Functional morphology of mountain plants. Flora 182:353-383

Körner C, Diemer M, Schäppi B, Niklaus P, Arnone J (1997) The responses of alpine grassland to four seasons of $\mathrm{CO}_{2}$ enrichment: a synthesis. Acta Oecol 18:165-175. https://doi.org/10.1016/S1146609X(97)80002-1

Latzel V, Janeček Š, Hájek T, Klimešová J (2013) Biomass and stored carbohydrate compensation after above-ground biomass removal in a perennial herb: does environmental productivity play a role? Folia Geobot 49:17-29

Menke JW, Trlica MJ (1981) Carbohydrate reserve, phenology, and growth cycles of nine Colorado range species. J Range Manag 34:269-277. https://doi.org/10.2307/3897849

Möhl P, Hiltbrunner E, Körner C (2020) Halving sunlight reveals no carbon limitation of aboveground biomass production in alpine grassland. Glob Change Biol 26:1857-1872. https://doi.org/10. $1111 /$ gcb. 14949
Monteith L, Unsworth MH (2013) Principles of Environmental Physics. Plant Anim Atmos. Fourth Edition. Academic Press, Elsevier

Mooney HA (1972) The carbon balance of plants. Ann Rev Ecol Syst 3:315-346. https://doi.org/10.1146/annurev.es.03.110172.001531

Mooney HA, Billings WD (1960) The annual carbohydrate cycle of alpine plants as related to growth. Am J Bot 47:594-598. https:// doi.org/10.1002/j.1537-2197.1960.tb14911.x

Orthen B, Wehrmeyer A (2004) Seasonal dynamics of non-structural carbohydrates in bulbs and shoots of the geophyte Galanthus nivalis. Physiol Plant 120:529-536. https://doi.org/10.1111/j. 0031-9317.2004.0284.x

Patty L, Halloy SRP, Hiltbrunner E, Körner C (2010) Biomass allocation in herbaceous plants under grazing impact in the high semiarid Andes. Flora 205:695-703. https://doi.org/10.1016/j.flora. 2009.12.039

Pinheiro J, Bates D, DebRoy S et al (2014) nlme: linear and nonlinear mixed effects models. R Package Vers 3:1-177

Pollock CJ, Cairns AJ (1991) Fructan metabolism in grasses and cereals. Ann Rev Plant Physiol Plant Mol Biol 42:77-101. https://doi. org/10.1146/annurev.pp.42.060191.000453

Poorter, H, Garnier E (2007) Ecological significance of inherent variation in relative growth rate and its components In: Pugnaire FI, Valladares F (eds) Functional plant ecology. CRC Press, Boca Raton, pp 67-100 https://doi.org/10.1201/9781420007626

Poorter H, Nagel O (2000) The role of biomass allocation in the growth response of plants to different levels of light, $\mathrm{CO}_{2}$, nutrients and water: a quantitative review. Aust J Plant Physiol 27:595-607. https://doi.org/10.1071/PP99173_CO

Poorter H, Remkes C, Lambers H (1990) Carbon and nitrogen economy of 24 wild species differing in relative growth rate. Plant Physiol 94:621-627. https://doi.org/10.1104/pp.94.2.621

Poorter H, Jagodzinski AM, Ruiz-Peinado R, Kuyah S, Luo YJ, Oleksyn J, Usoltsev VA, Buckley TN, Reich PB, Sack L (2015) How does biomass distribution change with size and differ among species? An analysis for 1200 plant species from five continents. New Phytol 208:736-749. https://doi.org/10.1111/nph.13571

R Core Team (2014). R: A language and environment for statistical computing. R Foundation for Statistical Computing, http:// www.R-project.org/

Rasband WS (2014) ImageJ. U. S. National Institutes of Health, Bethesda, Maryland, USA. http://imagej.nih.gov/ij/, 1997-2014

Scherrer D, Körner C (2011) Topographically controlled thermal-habitat differentiation buffers alpine plant diversity against climate warming. J Biogeogr 38:406-416. https://doi.org/10.1111/j.13652699.2010.02407.x

Scherrer D, Schmid S, Körner C (2011) Elevational species shifts in a warmer climate are overestimated when based on weather station data. Intern J Biomet 55:645-654. https://doi.org/10.1007/ s00484-010-0364-7

Shaver G, Billings W (1976) Carbohydrate accumulation in tundra graminoid plants as a function of season and tissue age. Flora 165:247-267. https://doi.org/10.1016/S0367-2530(17)31854-6

Steffen S, Dillenberger MS, Kadereit JW (2016) Of dwarfs and giants: phylogeny of the Petasites-clade (Asteraceae-Senecioneae) and evolution of miniaturization in arctic-alpine environments. Plant Syst Evol 302:545-559. https://doi.org/10.1007/ s00606-016-1282-x

Studer MS, Siegwolf RTW, Abiven S (2014) Carbon transfer, partitioning and residence time in the plant-soil system: a comparison of two ${ }^{13} \mathrm{CO}_{2}$ labelling techniques. Biogeosciences 11:1637-1648. https://doi.org/10.5194/bg-11-1637-2014

Tolsma AD, Read SM, Tolhurst KG (2007) Roots of Australian alpine plant species contain high levels of stored carbohydrates independent of post-fire regeneration strategy. Aust J Bot 55:771-779. https://doi.org/10.1071/BT06216 
Turgeon R (1989) The sink-source transition in leaves. Ann Rev Plant Physiol Plant Mole Biol 40:119-138. https://doi.org/10.1146/ annurev.pp.40.060189.001003

van der Werf A, Visser AJ, Schieving F, Lambers H (1993) Evidence for optimal partitioning of biomass and nitrogen availabilities for a fast- and slow-growing species. Funct Ecol 7:63-74. https://doi. org/10.2307/2389868

van der Werf A, Geerts R, Jacobs F, KorevaarH., Oomes, M, de Visser W (1998) The importance of relative growth rate and associated traits for competition between species during vegetation succession. Inherent variation in plant growth. In: Lambers $\mathrm{H}$, Poorter H, Van Vuuren M (eds) Physiological mechanisms and ecological consequences. Backhuys, Leiden, pp. 489-502

Wong S-C (1990) Elevated atmospheric partial pressure of $\mathrm{CO}_{2}$ and plant growth. Photos Res 23:171-180. https://doi.org/10.1007/ BF00035008

Wyka T (1999) Carbohydrate storage and use in an alpine population of the perennial herb, Oxytropis sericea. Oecologia 120:198-208. https://doi.org/10.1007/s004420050849 